\title{
THE BULLYING PHENOMENON AMONG STUDENTS AS MEDICAL AND PSYCHOLOGICAL PROBLEMS
}

\section{Khliestova S. S., Chorna V. V.}

\section{INTRODUCTION}

Since ancient times the violence, which was manifested by aggression and still remains in modern society is one of the unsolved problems of society. Most of all teens and students are suffering, but adults who have a predisposition to mental and psychological disorders may suffer from such phenomena too. Incidents of violence among students can be separate and long-term, which in turn leads to mental disorders and sometimes to suicide acts. The Constitution of Ukraine as the main state document confirm that the life and health of every person, their honor and dignity, integrity and security are the highest social values. "No one shall be subjected to torture, cruel, inhuman or degrading treatment or punishment"1.

However, the phenomenon of psychological and physical violence does not stop to amaze society with its scale. Prominent British scientists D. Lane and $\mathrm{E}$. Miller, exploring the problem of aggression, called this phenomenon billing. The term "bullying" - considered to be international, as in the twentieth (XXI) century this phenomenon has been the subject of scientific research from many countries of the world such as Brazil, Great Britain, India, Canada, Norway, Portugal, United States, Finland, Japan and many others.

Of course, a baby is not born with that particular gene of bullying which is waiting for favorable conditions or circumstances to begin its destructive action. Most understand that a person who behaves in this way is the product of complex social processes that, through imperfect education and upbringing, create an antisocial personality, prone to aggressive manipulation by other people, as a rule, weaker. As long as models of socialization, including gender, will be imperfect, inappropriate for the development of modern society, people will be educated who will initiate the billing of the youth student environment ${ }^{2}$.

${ }^{1}$ Конституція України: станом на 15 березня 2018 р. / Верховна Рада України. Харків : Право, 2018. 76 с.

${ }^{2}$ Кон И.С. Что такое буллинг и как с ним бороться? Семья и школа. 2006. № 11. C. $15-17$. 
Statistical data of the World Health Organization (WHO) give reason to believe that Ukraine ranks fourth in Europe in terms of aggression of teenagers and students. The effects of bullying are both personal and social. Adolescents or students who exhibit abusive behavior at school, college, or university with respect to their peers and teachers are usually also prone to criminal activity in adulthood. More often, teenagers and students who have previously been bullied are also at risk of bullying. Very often their accumulated resentment transpose into aggressive criminal actions to the environment ${ }^{3}$.

Over the last 10 years of social, economic, political and conflict situation in Ukraine, psychological and physical bullying has become a daily routine of student life. Most often victims of bullying are teenagers or students who have defects in appearance (strabismus, red hair, overweight); physical defects (wearing glasses, hearing aids, limping); chronic diseases (stuttering, enuresis, impaired speech); low intelligence and learning difficulties; lack of social adaptation, problems in the team-work.

Unfortunately, the phenomenon of physical and psychological abuse among young people is not recognized by the Law of the Penal Code as requiring punishment of the offender or the bully and compensation to the victim. The gaps of prevention work on the phenomenon of bullying among adolescents and young people threaten not only victims of psychological and physical abuse, but also national security of the whole Ukraine.

The problem of bullying remains relevant and unsolved, both practically and theoretically. Therefore, the purpose of our study is to carry out a retrospective analysis of the concept of "bullying" as a whole phenomenon, to reveal the historical chronology and significance of scientific research on the problem of violence, to experimentally determine and determine the percentage of victims who were exposed to the phenomenon of bullying among students and identify the professional role of the psychologist in solving the problem of bullying in the student environment.

\section{Retrospective analysis of the concept of "bullying" as a whole phenomenon}

The problem of baiting, ridicule, and violence against children arose in the 1980 s. French scientist K. Ducks was indifferent to such social phenomenon. He studied for a long time the problem and its consequences, so he was the first who published his scientific work, it was in 1905. The

\footnotetext{
${ }^{3}$ Social determinants of adolescent health and well-being. Health Behavior of Schoolaged Children Study: International Survey Report 2009-2010 / ed. C. Currie. Copenhagen : Europe. region. WHO Bureau. (Ser. Children's and Adolescent Health Policy), 2012. Vol. № 6. P. 56-57.
} 
successors in the study of violence were outstanding Austrian psychologists and psychiatrists A. Adler, W. Shtekel and Freud. With their initiative in 1910 in Vienna passed the congress dedicated to "suicide, in particular, suicide among those who are in school". In his report, Z. Freud stated that: "It is not only the school that can be accused of so much violence and that children commit suicide, but it is the school's fault that it does nothing to resist this at least trends".

The problem of violence against people became more relevant only in the 60's and 70's twentieth (XX) century in Scandinavia. Studying this problem, the Scandinavian scientists E. Roland, A. Picass, and P. Heinemann began to treat violence as bullying, which meant bully, impostor or a person who intimidates the weaker to cause mental or physical harm. Then the British researchers D. Lane, E. Miller, E. Munte, V. Orton, D. Tatum showed their scientific interest in the problem of studying bullying as a concept and phenomenon in general. They have associated this phenomenon as a process of long-term conscious psychological or physical abuse of one person or group of persons by another ${ }^{4}$.

E. Adamson, I. Kohn, H. Leiman, K. Lorenz, D. Olveus, J. Hazler should be considered as the founders of the study of the billing phenomenon. It was the theoretical aspects of the problem in 1978 that interested Norwegian scientist D. Olweus. His purpose was to develop a model of billing in the educational environment, which served as the basis for further scientific study of the problem.

In 1989, the scientist psychologist W. Besag described the phenomenon of bullying as a behavior that is determined by repeated attacks of the buller, namely: psychological, physical, social or verbal. In this situation, the power of the bully is formally or situationally higher to those who cannot defend themselves. The intentions of the bully are manifested in causing the victim's suffering for his own satisfaction. In the United States, the problem of bullying has attracted the attention of scientists in the early 90's of the twentieth century. American educational theory details methodological principles for preventing and combating youth violence ${ }^{5}$.

However, long-term research by the Norwegian scientist psychologist D. Olveus in 1993 gained considerable scientific popularity of the phenomenon of bullying in the environment of psychological science. His research and scientific developments and models of the structure of bullying

${ }^{4}$ Лэйн Д.А. Школьная травля (буллинг). Детская и подростковая психотерапия / под ред. Д.А. Лэйна и Э. Миллера. Санкт-Петербург, 2001. С. 240-274.

${ }^{5}$ Champion Kelly, Vernberg Eric, Shipman Kimberly. Nonbullying victims of bullies: Aggression, social skills, and friendship characteristics. Applied Developmental Psychology. 2003. № 24. P. 535-551. 
in the youth environment later became a global trend of psychology. Research in the fields of phenomenology and scientific technology on the prevention and interruption of bullying has begun to develop rapidly in the medical and psychological field. The author's scientific research identifies three important components of bullying, namely: bullying as aggressive behavior, including unwanted, negative actions; bullying as a model, pattern, and stereotype of behavior that is adopted over time in a particular culture; bullying as an imbalance of domination, status or power ${ }^{6}$.

Exploring the situation of bullying among adolescents, in 1994, S. Arora, a scientist, concluded that certain types of observable bullying are called communication between young people at school, college, or university and cause feelings of hurt or stress.

The analysis of scientific works gives an opportunity to determine the specifics and main features of bulling among teenagers and student youth who are inherent in:

- systematic phenomenon;

- inequalities in the physical, psychological and social capacities that underlie the relationship between the victim and the bully;

- the relationship between the bully and the victim;

- emotional humiliation, an offense to personal feelings, which leads to the exclusion from the group.

The problem of bullying in the post-Soviet countries has only become scientifically relevant since the 2000 s of the 21 st century. Scientists S. Volykov and O. Kalinkin have investigated that from 2003 to 2012 the number of fixed appeals of adolescents and students to trust services through harassment and violence has increased significantly. In today's society, it has become a pan-European trend.

Analysis explanatory dictionary of scientific literature gives reason to believe that the term "bullying" is of English origin. In the Cambridge Dictionary, the verb "to bully" means to insult or intimidate someone who is less on age, less influential than an attacker or socially disadvantaged person. The interpretation of the term "bullying" in the Oxford Dictionary means the desire to cause psychological or physical harm, to intimidate or force an undesirable action of a vulnerable, weaker person ${ }^{7}$.

The essence of projective strategies for preventing violence is rightly revealed in the works of J. Botwin, D. Hamburg, L. Kolberg, S. Mikhelik,

${ }^{6}$ Smith, P. Bullying in schools: Thirty years of research. In C. Monks, I. Coyne (Eds.). Bullying in Different Contexts Cambridge: Cambridge University Press. 2011. 36-60 pp. doi:10.1017/СВО9780511921018.003

${ }^{7}$ Король А. Причини та наслідки явища булінгу. Відновне правосуддя в Украӥні. 2009. Вип. 13. № 1. С. 84-93. 
E. Higgins, P. Chamberlain, and others. Reactive strategy against violence in general education institutions highlighted in the studies of L. Gaines, D. Hotfredsona, B. Kippera, R. Skibo, James. Freiberga and others.

The formation mechanisms of violent and aggressive behavior among adolescents and students were considered in the writings of American psychologists: L. Berkovitz, K. Webster-Stretton, M. Wolfang, L. Dolberg, D. Cornell, R. Lober, D. Ferrington, and I. Ferrakuti and others. In particular, foreign scientists M. Borba, D. Elliot, P. Naylor, D. Olveus, P. Orpines, etc. explored ways of preventing and overcoming negative violent phenomena.

According to the scientist D. Olveus, bullying victims are closed, shy, anxious, unsure of themselves, unhappy, has low self-esteem, depressed teenagers and students who have no close friend and are limited in dealing with adults close to them. However, strong, talented personalities can also provoke mockery. When at school, college, or university, a talented teenager or student launches self-determined mechanisms for developing bulling, willfully cause envy and annoyance by peers with a high level of knowledge, skills, and curiosity. As a result of this process, a $g$ talented teenager or student is isolated from the school or student team.

Kohn's scientific statement is correct, which states that bulling is a complex phenomenon, it has neither a clear explanation nor a universal way of overcoming and preventing it, but it has a global and mass character. The social and psychological bases of bulling are aggression, envy, domination, status, clashes of different subcultures, competition, struggle for leadership, the bully mental defects, lack of subjective leisure and more. It is a social individual behavior, manifested in a relatively stable groups and able to attract others. The psychological problem is that bullying covers the inequality of power and domination, which in turn puts the victim in a state where she is unable to effectively defend herself against negative action.

Thus, bulling can be classified into the following forms, which are generally accepted in the scientific psychological sense. Physical bullying is treated as deliberate blows, kicks, beatings, bodily harm to teenagers and students, etc. Psychological bullying is interpreted as violence that is associated with an action on the psyche that causes psychological trauma through verbal abuse or threats, harassment, intimidation, which deliberately inflicts emotional uncertainty on the victim. Emotional bullying is manifested by mockery, humiliation in the presence of others, appropriation of nicknames and ridicule. Sexual bullying is considered a subspecies of physical violence more common among students. Cyberbullying involves demeaning through mobile phones in the form of videos, the Internet, and other electronic resources. 
Therefore, the American physician S. Kempe defined sexual abuse of adolescents as "engaging functionally immature individuals in a sexual act that they do, not fully understanding, to which they are unable to consent, or that violate the taboo of family and social roles" 8 .

The well-known scientist V. Petrosyants in his scientific works assigns a separate role for each bullying participant - the buller, the victim and the observers. Thus, teenagers or students who have social weight, greater physical strength, consistently high potential for aggression, a self-affirmation and selfesteem, unbalanced psyche and deviant behavior can act as a bully. Victims are often obedient teenagers or students who become the target of psychological, physical or other abuse. The role of observer or witness may be teenagers or students who will brazenly, overtly observe violence, and rejoice. By such immoral acts, they seek to protect themselves from collective isolation and to "be like everyone" or not to be a "black sheep".

Ongoing research of prominent foreign and domestic scientists and expert work of international NGOs that are engaged in the problem of human violence allowed to develop global programs, the content of which is generalized, systematized set of recommendations to address the problem bullying among teenagers and students. At the global level, the program has been recognized by experts from different countries and is successfully operating in the United Kingdom, Norway, the United States of America, both at the national and regional levels. The analysis of this program and the experience of its implementation is quite valuable for social and pedagogical practice of Ukraine. As the data of the National Center for Educational Statistics of the United States convincingly prove the positive developments of the participants of this program, which are manifested in the reduction of cases of violence and threats increased by almost $50 \%$. There is an improvement in the socio-psychological climate in schools, colleges and universities. The number of discipline violations has decreased significantly. Theoretical and methodological measures for safe educational environment of the institution with motivation for successful educational activity have been developed ${ }^{10}$.

The UK's experience in preventing and overcoming the phenomenon of bullying in the educational environment is interesting and effective. For

${ }^{8}$ Swearer S.M., Hymel S. Understanding the psychology of bullying: Moving toward a social-ecological diathesis-stress model. American Psychologist. 2015. Vol. 70(4), 344353. https://doi.org/10.1037/a0038929.

9 Петросянц В.Р. Психологическая характеристика старшеклассников, участников буллинга в образовательной среде, и их жизнестойкость : дис. ... канд. психол. наук : 19.00.07 / Российск. госуд. педагог. ун-т. Санкт-Петербург. 2011. 210 с.

${ }^{10}$ Понамарев В.В. Исследование акцентуаций характера участников буллинга в контингенте подростков регионального социального заведения для несовершеннолетних. Мир медицины и биологии. 2013. № 3. С. 126-130. 
example, in 2006 the UK Ministry of Education developed recommendations and strategies aimed at preventing and eradicating bullying in schools. The priority was the adoption of the Regulations on Bullying, which provide involvement of parents, teachers, the student community, representatives of educational management authority and the police; the appointment of a teacher or psychologist who should be responsible for addressing issues related to bullying, whose duties is to monitor the behavior of others; setting up a trust center at a school, counseling and providing the necessary psychological assistance; inclusion of issues related to bullying in curriculum and adds subjects such as "Personal, Social and Health Education", which focuses on the basics of psychology, social life and a healthy lifestyle; "Citizenship classes", which is dedicated to the rights and responsibilities of the citizen; activities : "Antibullying Week", which should be aimed at raising awareness and medicalpsychological conferences ${ }^{11}$.

In 2018 the Parliament of Ukraine approve a bill that provides a fine for bullying. Under the law, teenagers, students, their parents, teachers and the headquarters of an educational institution may be prosecuted.

The Council of Europe launched a special three-year project on combating bullying and extremism in Albania, which was launched in 2019. The project's priorities are human rights and democracy, eradicating bullying and creating a safe educational environment.

\section{Experimental study of the phenomenon of bullying among student youth}

According to a study by the Ministry of Justice of Ukraine, $45 \%$ of children in the Transcarpathian region were humiliated. In the city of Chernivtsi, $41 \%$ of adolescents have once suffered a moral humiliation, physical abuse $-27 \%$; group attacks $-14 \%$; robbery $-12 \%$; sexual threat $8 \%$ (high school students and students). As a result of anonymous survey in schools in Kyiv $42 \%$ of people consider themselves victims of violence. However, $69 \%$ of teachers at these institutions do not consider that their students have been abused. We have found that teachers, when communicating with adolescents or students, may also exhibit behaviors that may cause them psychological pain. Therefore, in the questionnaires, children indicated that $-53 \%$ of teachers demand to stop quarrels, and 33\% of teachers - do not pay attention to it; it is up to $14 \%$ of teachers to lay over the conflict resolution, and $37 \%$ of schoolchildren consider ending the bullying phenomenon by conversations. The number of respondents who

\footnotetext{
11 Лушпай Л.І. Булінг як соціально-педагогічна проблема та шляхи її вирішення (на прикладі досвіду середніх загальноосвітніх шкіл Великої Британії). Українознавчий альманах. 2010. Вип. 4. С. 126-131.
} 
seek to involve psychologists in solving the problem is 46\%; law enforcement officers $-39 \%$ and $15 \%$ of specialists of public organizations ${ }^{12}$.

The statistics from the KidsPoll website confirm the results of a survey of 1200 teenagers and students, according to which the victims of bullying were $-48 \%$ of respondents, $15 \%$ of them were repeatedly abused, $42 \%$ of respondents said they were engaged in bullying and $20 \%$ of respondents confessed that they were engaged constantly.

Our experimental study on the phenomenon of bullying among student youth required analysis of its results in order to determine the number of cases of psychological or physical results and their consequences.

The medical-psychological experiment of the phenomenon of bullying among student youth took place in three stages on the basis of Vinnytsia National Pirogov Medical University and the State Educational Institution "Center of Sphere and Service" based in Zhytomyr. Methods of research were content-analysis of scientific sources, world programs and bills, which had analytical character; a comparative one, by means of which a retrospective characterization of the study of the problem of bullying was carried out as a phenomenon in general and in particular in the students society; a survey through our own designed questionnaire and Bass-Darka questionnaire.

The experiment involved 546 people. We invited curators of academic groups, teachers, heads of student self-government bodies, representatives of student social services, psychologists and practical psychologists to conduct the experimental research as experts and assistants. 400 students participated in the survey were from the Vinnytsia National Pirogov Medical University (77,8\% of them women and 22,3\% men) and 146 students of the State educational institution "Center of sphere and service" of Zhytomyr city $(85,6 \%$ - women and $14,4 \%$ - men). All experiment participants agreed to participate in the survey. They have been reports of complete confidentiality.

${ }^{12}$ Барліт О.О. Форми і методи подолання (мінімізації) соціально-педагогічної та психологічної проблеми булінгу в освітньому середовищі. Горизонти освіти: Науково-методичний журнал. 2012. № 2 (35). С. 44- 47. 


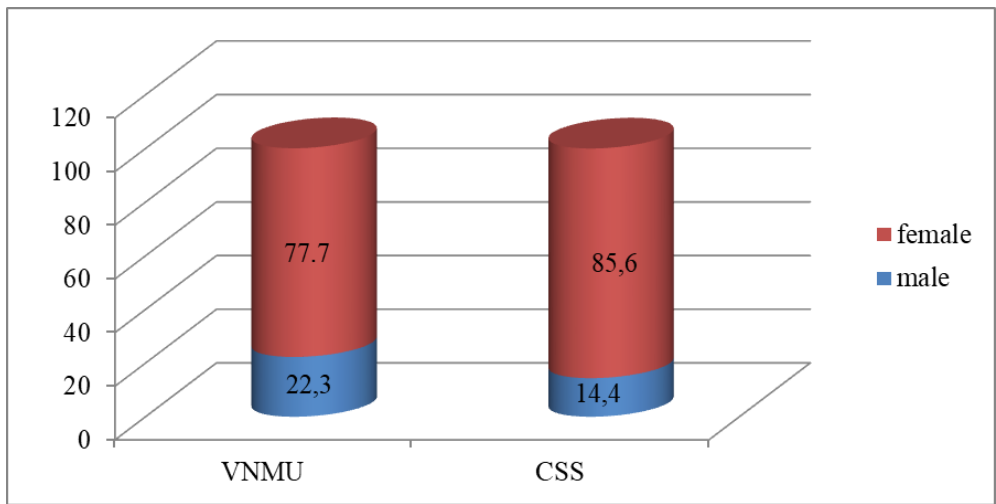

Fig. 1. Gender distribution of respondents in educational institutions

The method of anonymous survey, we questioned whether students are faced with the bullying phenomenon in the environment. We emphasized that the answers should be forthright and reassured respondents of anonymity. Therefore, we are confident that the figures provided are correct.

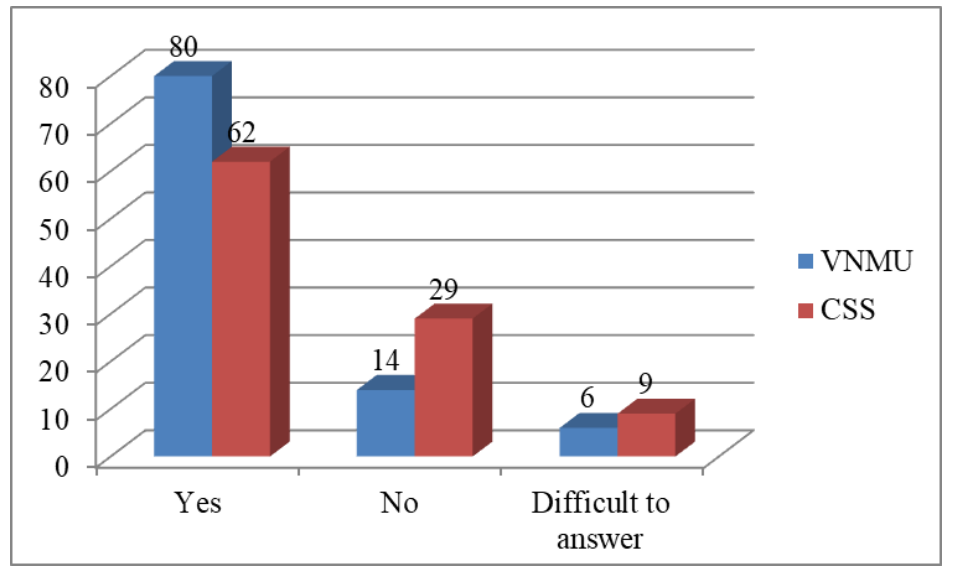

Fig. 2. The level of indicators of the phenomenon of bullying experienced by students

Taking into account the indicators of the previous graphic data, the next stage of the experimental part of the study was to identify the percentage of observers on the phenomenon of bullying among student youth. The role of 
observers or indifferent witnesses is that they are not involved in violence. However, they can be a danger to society because they are indifferent to the situation and do not divulge information to others (friends, students, teachers).

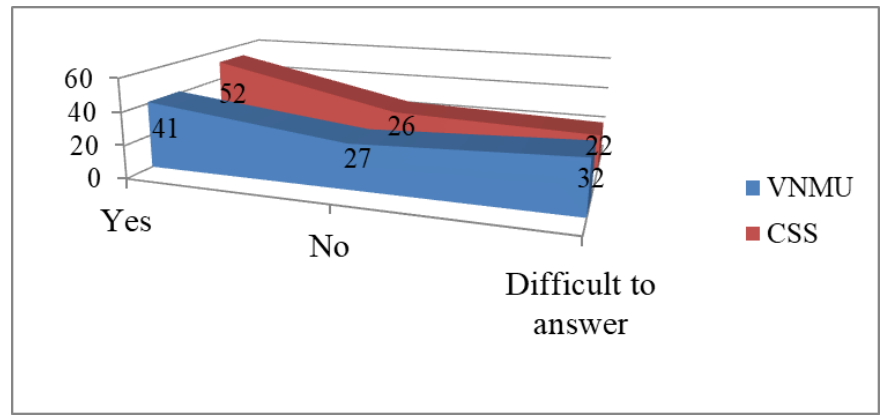

Fig. 3. The level of indicators of the phenomenon of billing observed by students

Existing types of bullying (physical, psychological, sexual and cyberbullying) are different in character, but the consequences of the victim are almost identical - moral humiliation, psychological and physical trauma, the exclusion of an individual from a group or team. Therefore, we have obtained the following predominant bullying results.

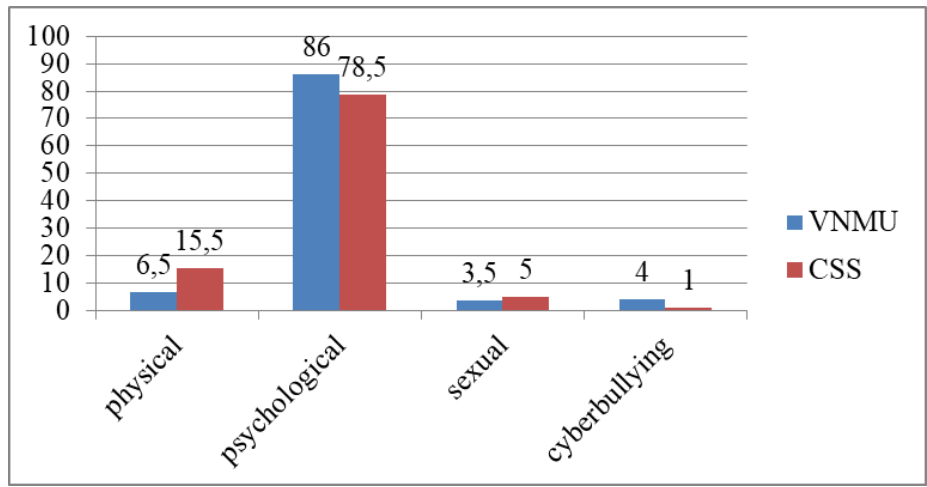

Fig. 4. The level of bullying performance prevalent among students

The phenomenon of bullying implies a process of role structure in which each involved participant seeks to choose the role that he can play. The phenomenon of bullying implies a process of role structure in which each 
involved participant seeks to choose the role that he can play. As a rule, the victim has no right to choose. Only direct or combined enemy and witnesses have that opportunity.

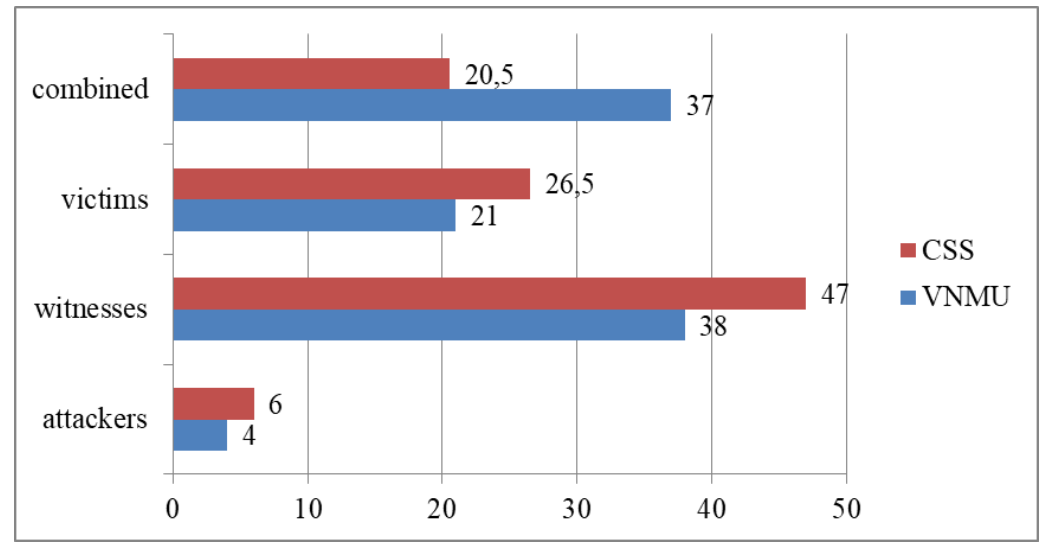

Fig. 5. Level of indicators of the roles chosen by the students

The determined dynamics and obtained figures of graphic images became the basis for further investigation of the problem. Given the gender distribution, the percentage of females is higher than males, so more girls are affected by bullying (Fig. 1). The level of indicators of the phenomenon of bullying experienced by students and the level of indicators of the phenomenon of bullying observed by students in educational institutions with the answer "yes" were the highest (Fig. 2, Fig. 3). The level of indicators of the types of bullying, which is most affected by students, the most impressive is psychological (Fig. 4). The level of role indicators chosen by the students are witnesses who observe the phenomenon, console themselves or receive spiritual pleasure and do not disclose to others about such crime. Victims of any bullying phenomenon, especially psychological ones, are closer to commit a suicide. Therefore, provided medical and psychological help in time will be able to save the life of a young person.

In the course of further research, we asked students whether they asked for help from psychologists or psychiatrists. Student results from Vinnytsia National Pirogov Medical University were as follows: only 2\% of students sought specialized help, $17 \%$ of students sought non-specialized assistance, and $81 \%$ of students did not seek help because they were afraid of mockery.

The results of the survey of the State educational institution "Center of sphere and service" of the city of Zhytomyr are more comforting, but also 
need some correction. When asked "Did you seek specialized help?" - 5\% said "yes"; applied for non-specialized assistance $-20 \%$ and did not apply at all $-75 \%$.

The analysis of the obtained results facilitated the introduction of scientific correction in the educational process of selected educational establishments. Our program of educational training and its conduct, antibullying propaganda among student youth and creation of an informationconsulting center made it possible to reach all participants of the educational process of Vinnytsia National Pirogov Medical University and the State Educational Institution "Center for Sphere and Service" Zhytomyr. During all stages of the experiment, which ran from January 2019 to January 2020, we obtained the results of a solution that testifies to the effectiveness of the implementation of interactive methods of preventing the phenomenon of bullying among student youth.

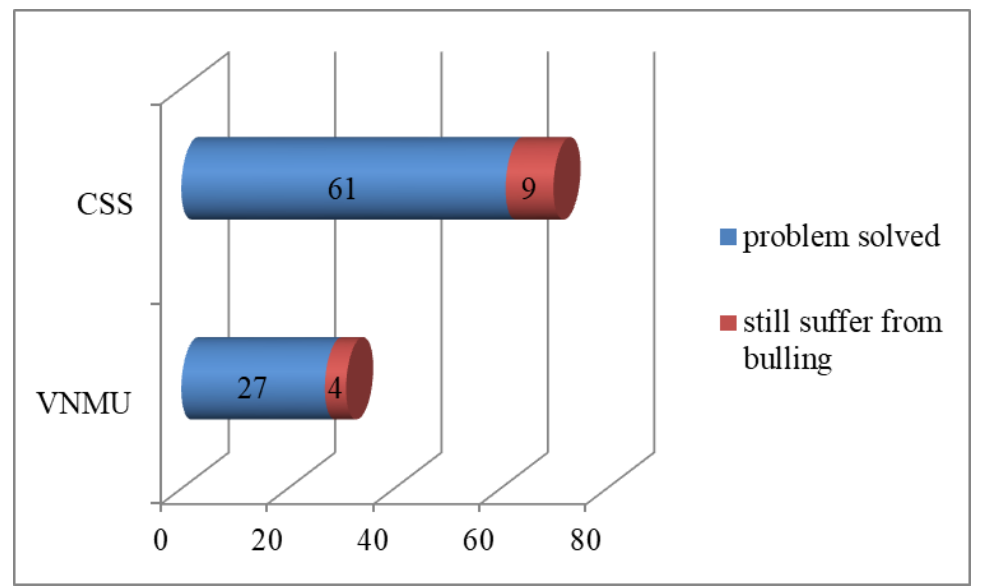

Fig. 6. Level of indicators of affected students after bullying after implementation of interactive methods

Students' age had certain characteristics. According to the results of the questionnaire, students of the State educational institution "Center of sphere and service" of the city of Zhytomyr aged 15-16 years, among women, $38,1 \%$ witnessed bullying and they were dominated by verbal aggression. And among men, 30,7\% were victims of bullying, negativism was prevalent. Among girls 17-18 years, 34,7\% witnessed harassment and they were dominated by negativism, and $37,5 \%$ were boys, while witnessing the predominance of indirect aggression. Among the students of Vinnytsia 
National Pirogov Medical University, women of 17-18 years old accounted for $41 \%$ of the victims of these events, and they noted negativism. Male respondents $-32 \%$ were witnesses, assailants, and victims of verbal aggression. Girls aged 19-20 made up 31,3\% of the role of witnesses, and over the Bass-Darka questionnaire an irritation prevailed. Accordingly, 36\% of the boys were victims, witnesses and assailants, and they were dominated by negativism. Among 21-22 year olds, 36\% were witnesses with overwhelming negativism, and $72 \%$ of students in this age group were both witnesses and victims and attackers with a predominance of verbal aggression. Thus, $86 \%$ of students consider the problem of bullying is relevant, due to the fact that $86,5 \%$ suffered from it during school years and $31,5 \%$ encountered it at university. Of these, $82,5 \%$ did not receive the necessary psychological help which they needed. Numerous studies have found that the consequences of bullying are serious for all involved, both for the bull, the witness and the victim.

The Ukrainian Institute for the Study of Extremism recognizes that violence goes through several stages: child bullying, radicalization, violent extremism, and terrorism. Bulls are prone to fights, thefts, alcohol and smoking, they have low grades in academic subjects, and they can also carry weapons. Witnesses may feel in danger. They may experience fear, inability to act, a sense of guilt for inaction, and may also be tempted to join the process and become a bully, especially if they do not have a steadfast attitude to the situation. The victim is negatively affected by bullying, which hinders socialization, causing inadequate self-perception, various phobias, depressions, neuroses, deviant behavior, various addictions, in which the victim wants to relieve mental tension, capable of suicidal suffering for the purpose of stopping.

\section{The role of the psychologist in solving the problem of bullying in the student environment}

The role of the psychologist in the modern society is increasing in solving the problem and in preventing the consequences of the bulling phenomenon. The subject of the profession of doctor-psychologist is a person who needs medical and psychological help and treatment. The objects of his professional activity are the relationship between emotional, social, biological components of health and various types of diseases; system of medical, psychological and social measures aimed at preserving the health of the population; treatment, prevention and rehabilitation of persons with temporary and persistent life restrictions; reducing the risk of disease in vulnerable populations and preventing further development of the disease. 
The main theoretical knowledge of the subject area of the doctorpsychologist in providing qualified assistance to the victims of the phenomenon of billing is medical psychology, which studies the general and individual psychological patterns of changes and restoration of mental activity of the person in various pathological conditions, with maladaptation of personality, their psycho-diagnosis and psychopsychiatry and psychoprophylaxis $^{13}$.

The profession of doctor-psychologist is considered to be still young, but it has already gained its relevance and significance. The specificity of the professional activity of a psychologist is connected with the peculiarities of the specialty itself and the social and psychological conditions that accompany it. The main criteria for the formation of a psychologist is to treat yourself as a professional, to have a positive attitude to your chosen profession, and to have a personally meaningful awareness of belonging to it. The professional identity of a psychologist, unlike other doctors, is characterized by a slightly different structure and stages of professional development and improvement.

A qualified psychologist is required to be able to conduct clinical interviews and diagnostic interviews to help identify the problem; have the skills of psychopsychiatric, functional, syndromic and differential diagnostics; able to apply the methods of psychological, psychotherapeutic and psychological-social influence on the affected person and other innovative medical-diagnostic knowledge, skills. The workplace of the psychologist must be equipped with a variety of psychological devices, audio and video equipment, computer and multimedia equipment; expenditures for psychological impact, means of psychodiagnosis and rehabilitation; library resources that will help you quickly identify, diagnose, treat, and prevent a problem.

The consequences of the phenomenon of bullying among students have different psychological and psychiatric course and are diagnosed by a psychologist. However, psychological states of victims and bullers are mostly of one nature, which is manifested in the severity of the reaction to stress, disorders of consciousness, psychomotor excitation of various genesis (manic, epileptic, organic, personality-anomalous) and the like. Psychopathic arousal and panic disorder in the person who observed the bullying and acute intoxication with psychoactive substances (including

${ }^{13}$ Yan H., Chen J., Huang J. School Bullying Among Left-Behind Children: The Efficacy of Art Therapy on Reducing Bullying Victimization. Front. Psychiatry. 2019. Vol. 10. P. 40-43. doi: 10.3389/fpsyt.2019.00040 
alcohol) in the person who caused the harm increased rapidly. Sometimes participants in the bullying phenomenon feels suicidal conditions.

With standard classic professional skills when dealing with people of any age who have been affected by violence, it is appropriate for a psychologist to use the skills of communicating effectively, establishing and maintaining contact with one person or a group; to conduct psychological consultancy, psychocorrection psychodiagnosis of personality, family and collective; assess risk factors and determine internal reserves for individual adaptation; resolve interpersonal, group and intergroup conflicts; make recommendations on creating and maintaining a favorable social and psychological climate in the staff of educational institutions; to analyze the dynamics of psychological processes inherent in healthy and sick person in group student groups; to control the course of physical and mental conditions in patients or clients; make recommendations for maintaining physical and mental health in general and addressing specific personality issues in particular.

The professional competence of the psychologist in solving the problem of bullying in the student environment and timely provision of qualified assistance to the victims will help to prevent or completely avoid unwanted consequences. Thus, the competence of the psychologist is the ability to think professionally on the basis of analysis and synthesis of phenomena, symptoms and syndromes of various types of pathology and defects of personality development, as well as to the objective manifestations of psychological problems. The psychologist conceives and formulates a complete functional diagnosis, collects information about the patient or client, makes the selection of optimal methods for conducting clinical or psychological diagnosis of the patient to interpret its results ${ }^{14}$.

Ability to evaluate the results of functional methods of diagnostics, laboratory and instrumental research, conducting psychological research and analysis, systematization, evaluation of psychometric and psychodiagnostic methods, formulation of reasoned conclusions and recommendations also help to achieve the desired results in identifying the problem of bullying in the student environment.

Specificity of medical-psychological activity of the doctor is to independently plan, organize and carry out psychological research, use valid and reliable psychodiagnostic tools, analyze and systematize the obtained results, formulate reasoned conclusions and recommendations without the

\footnotetext{
${ }^{14}$ Wahass S. H. The role of psychologists in health care delivery. Journal of family community medicine. 2005. Vol. 12(2). P. 63-70.
} 
help of junior medical staff. The prominent role of the psychologist depends on the scope, procedure and nature of the measures of providing medical and psychological assistance, using innovative technologies, ability to draw up and implement a plan of counseling process, take into account the age, gender, cultural, personal and other individual characteristics of the patient or client, selection of means and methods of medical care. Noteworthy is the choice of a range of optimal methods and the implementation of medical and psychological interventions to restore health, prevent somatic, mental, behavioral and psychosomatic disorders of student youth.

Of great importance in providing assistance depends on how effectively to establish psychological contact with a patient or client, the ability to organize and provide psychological assistance, to master and practically use methods of psychological and psychotherapeutic impact, to diagnose urgent conditions, to determine tactics and to provide emergency medicine. Professional decisions in difficult and unpredictable situations, providing first psychological help with psycho-emotional stress, life crises, suicidal intentions, recognizing cases that need urgent psychological help and choosing a tactic of assistance are considered to be a key responsibility of a psychologist.

The most important stage in the professional role of a psychologist is the ability to understand the limits of their competence and to constantly improve professional qualification, knowledge and practice of the norms of medicinal ethics and moral culture, the ability to adapt to new situations, to develop interpersonal skills and effective interaction with colleagues and effective interaction multidisciplinary teams.

Thus, defining the role of a psychologist in the contemporary medical, social and psychological contexts suggests that there are many obstacles to achieving these results. First of all, there is a lack of professional community of psychologists in Ukraine, since the training of these specialists has recently started, so their number is still objectively small; secondly, the unresolved issue of employment of psychologists, which reduces the selfesteem of graduates of this specialty and leads to a feeling of inferiority and superficiality by representatives of other medical specialties; third, a decrease in motivation for professional self-improvement and selfdevelopment as a result of instability, uncertainty and not too high appreciation for the chosen profession of psychologist.

Therefore, the importance of the professional role of a psychologist, professional qualification and employment should be a priority and addressed at the state level. 


\section{CONCLUSIONS}

Summarizing the above, we have reason to say that the phenomenon of bullying is a long process of conscious ill-treatment, which is accompanied by serious, sometimes lethal, medical-psychological, social-negative consequences and occurs out of school in uncontrolled places. Characteristically, the age young people (20-21 year) the level of aggression decreases. The functioning of the brake processes that influence the formation of norms and rules of behavior in the phenomenon of bullying, in the older student's age lose their relevance. Minimizing or completely overcoming the problem of bullying in the educational environment must be addressed at the state level. Creating and implementing educational programs, statutes and laws regarding the phenomenon of bullying in educational institutions will reduce the level of aggression of young people towards each other. The tolerant or neutral attitude of the administration of the educational institution, teachers and curators of student dormitories to the manifestation of aggressive, hostile or violent actions by students and the behavior of the teachers themselves creates a general atmosphere not only of the student group, but of the whole educational institution and creates a social climate.

Prospective measures for monitoring and periodic review of educational programs can become a prospect for further exploration of the problem of bullying among student youth in educational institutions. Introduce a mandatory annual anonymous survey of participants in the educational process and regularly publish the results of the bullying phenomenon among students on the official website of the institution or on the stands.

Educational institutions should organize for the promotion of medical and psychological qualifications and make public information on educational programs, higher education degrees and qualifications. The problem of bullying among the student environment in our country remains urgent and requires further careful research and finding ways to overcome it.

\section{SUMMARY}

The article presents a retrospective analysis of the phenomenon of bullying. The chronology of scientific developments and studies of human violence has been generalized and systematized. Theoretical views of the problem of billing of foreign and domestic scientists are covered. The causes and consequences of bullying among student youth in educational institutions are analyzed. The materials of the experimental study of the phenomenon of bullying and the level of aggression among students of educational institutions are presented. The degree of prevalence of bullying 
in Ukraine, the factors of origin and ways of prevention are analyzed. The role of the psychologist in solving the problem of bullying in the student environment is substantiated. The specificity of diagnosing and providing the first emergency medical and psychological help to the victims of bullying is substantiated.

\section{REFERENCES}

1. Барліт О.О. Форми і методи подолання (мінімізації) соціальнопедагогічної та психологічної проблеми булінгу в освітньому середовищі. Горизонти освіти: Науково-методичний журнал. 2012. № 2 (35). С. 44-47.

2. Лушпай Л.І. Булінг як соціально-педагогічна проблема та шляхи iii вирішення (на прикладі досвіду середніх загальноосвітніх шкіл Великої Британії). Украӥнознавчий альманах. 2010. Вип. 4. С. 126-131.

3. Конституція України: станом на 15 березня 2018 р. / Верховна Рада України. Харків : Право, 2018. 76 с.

4. Король А. Причини та наслідки явища буллінгу. Вiдновне правосуддя в Україні. 2009. Вип. 13. № 1. С. 84-93.

5. Кон И.С. Что такое буллинг и как с ним бороться? Семья $u$ школа. 2006. № 11. С. 15-17.

6. Лэйн Д.А. Школьная травля (буллинг). Детская и подростковая nсихотерапия / под ред. Д.А. Лэйна и Э. Миллера. Санкт-Петербург, 2001. C. $240-274$.

7. Петросянц В.Р. Психологическая характеристика старшеклассников, участников буллинга в образовательной среде и их жизнестойкость : дис. ... канд. психол. наук : 19.00.07 / Российск. госуд. педагог. ун-т. Санкт-Петербург. 2011. 210 с.

8. Понамарев В. В. Исследование акцентуаций характера участников буллинга в контингенте подростков регионального социального заведения для несовершеннолетних. Мир медищины $u$ биологии. 2013. № 3. С. 126-130.

9. Champion Kelly, Vernberg Eric, Shipman Kimberly. Nonbullying victims of bullies: Aggression, social skills, and friendship characteristics. Applied Developmental Psychology. 2003. № 24. P. 535-551.

10. Smith, P. Bullying in schools: Thirty years of research. In C. Monks, I. Coyne (Eds.). Bullying in Different Contexts Cambridge : Cambridge University Press. 2011. 36-60 pp. doi:10.1017/CBO9780511921018.003

11. Social determinants of adolescent health and well-being. Health Behavior of School-aged Children Study: International Survey Report 2009- 
2010 / ed. C. Currie. Copenhagen : Europe. region. WHO Bureau. (Ser. Children’s and Adolescent Health Policy), 2012. Vol. № 6. P. 56-57.

12. Swearer S. M., Hymel S. Understanding the psychology of bullying: Moving toward a social-ecological diathesis-stress model. American Psychologist. 2015. Vol. 70(4), 344-353. URL: https://doi.org/ $10.1037 / \mathrm{a} 0038929$.

13. Wahass S. H. The role of psychologists in health care delivery. Journal of family community medicine. 2005. Vol. 12(2). P. 63-70.

14. Yan H., Chen J., Huang J. School Bullying Among Left-Behind Children: The Efficacy of Art Therapy on Reducing Bullying Victimization. Front. Psychiatry. 2019. Vol. 10. P. 40-43. doi: 10.3389/fpsyt.2019.00040

\section{Information about the authors:} Khliestova S. S.,

Ph.D. in Pedagogic Sciences, Associate Professor at the Department of Medical Biology National Pirogov Memorial Medical University 56, Pirogov Str., Vinnytsia, Ukraine

Chorna V. V., Ph.D. in Medical Sciences, Senior Lecturer in the Department of Disaster Medicine and Military Medicine National Pirogov Memorial Medical University 56, Pirogov Str., Vinnytsia, Ukraine 